\title{
СТРАТЕГИЈА ЕКВИВАЛЕНЦИЈЕ У ПРАВНОМ ПРЕВОДУ ИЛИ КАКО ПРЕВЕСТИ НЕПРЕВОДИВО ИЗМЕЪУ ФРАНЦУСКОГ И СРПСКОГ ЈЕЗИКА
}

\begin{abstract}
У раду смо настојали да укажемо на различите стратегије које се употребљавају када је потребно изразити на српском односно француском језику појаву која је специфична другом правном систему. Четири технике су анализиране: функционална еквиваленција, формална еквиваленција, транскрипција и описни превод. Свака од ових техника има последице на комуникативном али и на идеолошком нивоу, на шта је потребно да преводиоци, аутори али и српски лексикографи обрате пажњу. тегије.

Кључне речи: српски језик, француски језик, правни превод, еквиваленције, стра-
\end{abstract}

У овом истраживању настојали смо да осветлимо један специфичан проблем везан за превођење, који се појављује пред преводиоцима правног текста. Наиме, често се поставља питање превода елемената који су специфични у једном правном систему, због чега смо у раду анализирали различите преводилачке стратегије код овог проблема на примерима француско-српског и српско-француског превода.

Традуктологија као наука је млада дисциплина, али проблеми којима се она бави имају вишевековно постојање. Наиме, једно од главних питања традуктологије је како превести речи или синтагме карактеристичне за дух једног језика. Потом проблеми везани за књижевни превод, нарочито када је о поезији реч, често су привлачили пажњу како преводилаца тако и лингвиста и књижевника (в. Тома 2018). Код књижевног превода јављају се и друге врсте питања, а то је на пример воља аутора. Односно колико би се један аутор сложио управо с конкретним одабиром одређене речи међу синонимима. Познати пример у традуктологији, када је реч о српском као пошиљаоцу и

\footnotetext{
*aleksandar.stefanovic@sorbonne-universite.fr
} 
француском као примаоцу је Андрићева „Госпођица”, код које је сам писац интервенисао током превода. Ипак, ситуација да аутор учествује у преводу је ретка, те и превод о коме је реч представља праву драгоценост за француску културу.

Питања специфична за књижевни превод, имају свој одјек и у правном преводу. Међутим, разлика је у томе што се правни превод, с једне стране, као и књижевни мора уклопити у дух језика који је прималац, а с друге стране, за разлику од књижевног, правни превод се некако мора уклопити и у правни систем државе на чији језик се преводи. Ова ситуација га чини једним од најсложенијих типова превода.

Правни превод, односно јуритрадуктологија постаје стварна потреба савременог друштва, јер су без ње незамисливе бројне сарадње између различитих земаља. Како на то указује Сузана Шарчевић (2012: 187), у савременом друштву можемо наћи велики број примера који показују да правно превођење подразумева комуникацијски чин који мора премостити језичке, културне и правне баријере како би омогућило функционисање права на више језика, било на националном, међународном или наднационалном нивоу. Међутим, поред овога правни преводиоци сусрећу се са још једним проблемом на који се често указује у оквиру јурилингвистике. Реч је о томе да правници употребљавају језик на начин који није сасвим довољно пажљив због чега се већ у оригиналном тексту могу створити проблеми који отежавају већ довољно комплексан правни превод. „Веза језика и права се потцењује, јер правна струка не обраћа пажњу на језик. Правници углавном гледају на језик као на алат, а не као на предмет проучавања" (Редли 2019: 227). Језик који користе правници треба да буде јасан и да отклони сваку потенцијалну двосмисленост, на шта су у својим радовима указали Максимовић (2006) и Редли (2019), као и други проучаваоци који се баве питањем језика у праву. Како то, ипак, често није случај, не само у Србији, него, на пример, и у Француској, преводилац има задатак и да текст који преводи најпре правилно разуме, у чему му могу помоћи једино правни приручници, као и познавање закона обеју држава (и језика пошиљаоца и језика примаоца).

Без обзира на различите тешкоће које се јављају код правнога превода, он је неопходан савременом друштву и светском поретку. Та неопходност видљива је у потреби коју савремено друштво све више показује, а која се огледа у премошћавању баријера различитих правних система. Настојећи да осветлимо нека од решења када је реч о овом проблему, у овом раду најпре смо указали на четири различите могућности превођења, односно на четири стратегије за налажење еквивалената у судском преводу. Међутим, пре него што се упустимо у стратегију проналажења еквивалената, чини нам се значајним да се осврнемо и на проблеме везане за правну интеркултуралност.

Право као дисциплина базира се на концептима који су суштински флуидни и нестабилни. То се најбоље може уочити када се обрати пажња на тешкоће које имају правници да се сложе око договора везаног за важне законске концепте као што су злочин против човечности или геноцид. Такође, иако су нека кривична дела попут убиства универзално призната, 
одређивање њихове правне природе, разликује се од земље до земље, односно од правног система до правног система. Поред тога, дефиниција једног концепта може у било ком тренутку бити измењена у оквиру истог правног система посредством законодавства или судске праксе (case law). У том контексту интересантан је пример везан за концепт претпоставке невиности (présomption d'innocence) који је знатно измењен Законом од 15. јуна 2000. у француском закону или случај пребацивања надлежности истражног судије судији за претходни поступак и тужиоцу у Србији након Закона о кривичном поступку из 2011. Правни текст се, дакле, мења и није окамењен како се то уобичајено замишља.

Из упоредне перспективе, ствари се још више компликују. У упоредној стилистици, одређене модификације потребне у преводу објашњавају се позивањем на поглед на свет или на чињенице металингвистике које се разликују од једног језика до другог (Вине/Дарбелне 1977: 258-269). Примера има много и налазе се у најразличитијим језичким сферама; медицинска: бол у стомаку - crise de foie = upset tummy; правно-журналистичка: изаћи на улиuy - descendre dans la rue $=$ take to the streets итд. У случају правног превода, поглед на свет условљен је правним системом дотичне државе. Не мења се само перцепција референта, него је заправо сам референт другачији. Тако би се могло говорити, у случају правног превода, о различитим стварносним световима како је на то у свом тексту указала Нина Рива (1981: 223). Међутим, иако одређени концепти прелазе границе једне нације, испоставља се да је, у поређењу са техничким и научним областима, право далеко више усидрено у концепту нације.

Сучељавање две правне културе открива одређену нескладност коју није увек лако премостити. Чак и ако у основи постоји заједнички фонд између два правна система, свака правна култура има своје особености, које дају конкретно место специфичним терминима. У неким случајевима постоји упоредиви референт у другој култури, чак и ако представља значајне разлике; у другим случајевима не постоји упоредиви референт. Ове међукултурне разлике представљају веома велики проблем за преводиоца правног превода. Ипак, када је реч о међукултурним правним разликама, могу се издвојити три главне врсте појмова који представљају највећи изазов за премошћавање међукултурних разлика. Ти појмови су:

- $\quad$ концепти [на пример, non-assistance à personne en danger (непружање помоћи лииу у опасности), témoin assisté (врста окривљеног у ширем смислу); оштећени као тужилаи];

- $\quad$ институције [(tribunal judiciaire (врста основног суда); привредни суд];

- правни актери [(правобранилач, судија за претходни поступак; éducateur (врста социјалног радника), greffier (врста судсков записничара)].

Превод са француског на енглески или обрнуто, односно превод са српског на француски или обрнуто представља додатну потешкоћу утолико што ставља две породице закона у опозицију. Те породице су романо-герман- 
ско право, с једне стране, и common law, с друге стране. Међутим, ствар је још сложенија када се има у виду да у неким случајевима опозиција постоји и у оквиру једне породице права, као што је то у самом романо-германском праву, где се јавља опозиција између француског и српског права. Из ових разлика произилази низ других тачака разилажења, која ставарју потешкоће за превод правнога текста.

Нескладност правних концепата о којој је реч може створити проблем и код еквиваленције која се на први поглед подразумева. Енглески правни уговор contract није ништа еквивалентнији француском уговору contrat, него што је српски уговор. Такође, енглески administrative law не значи исто што и на француском droit administratif односно на српском управно право, а исто је и код енглеског концепта civil law које не подразумева француско droit civil односно српско, грађанско право, а common law не значи droit commun/ опште право (в. Давид/Жофре/Спинози 1992: 273).

Имајући у виду примере које смо навели, чини се да је неопходно наћи прихватљива решења која минимализују недостатке код еквиваленција, и која успевају да одговоре потребама превода. Да би се одговорило изазову „превођења непреводивог”, могуће је идентификовати четири врсте еквиваленције које свесно или несвесно користе правни преводиоци или аутори правних текстова. Овде се чини важним и нагласити да термин „еквиваленција", када је реч о превођењу, нема своје математичко значење тачне кореспонденције између два ентитета. Термин еквиваленција, заправо, има прагматичније значење и подразумева могући превод чија је прихватљивост подложна одређеном броју варијабли. На овом месту занимљиво је и указати на практични утицај, као и идеолошке претпоставке, сваке стратегије у функцији тих варијабли. Базични постулат је да успешност једне технике превођења не зависи од њених квалитета, већ од адекватности између одабране стратегије и ситуације у комуникацији (тј. сврха преведеног текста и идентитет његовог примаоца).

Код поступака еквиваленције, када је реч о правном преводу, могу се издвојити четири начина еквиваленције. Ти начини могу се именовати као: функционална еквиваленција, формална еквиваленција, транскрипција и дескриптивна транскрипција. Све четири еквиваленције имају своје предности и недостатке и одабир једне од њих зависи првенствено од преводилачке ситуације, као и од текста који се преводи.

Функиионална еквиваленција је процес који се састоји у проналажењу у језику примаоцу референта који врши сличну функцију коју има задати еквивалент у језику пошиљаоцу. Овакву адаптацију називамо интеркултурална адаптација. Као примере можемо навести у француском правосуђу Cour d'Assises који као приближан еквивалент у српском правосуђу има назив Виши суд или у енглеском правосуђу Crown Court (за однос француско правосуђе - енглеско правосуђе в. Чалмерс 1994: 15), или још commission rogatoire формулација која у француском правном систему одговара ономе што је у српском правном систему замолница. Будући да неизбежно постоје разлике у денотацији и конотацији између два, односно три референта, преводилац се мора осигурати да су те разлике прихватљиве у датом контексту. 
Ова техника је естетски задовољавајућа, јер појам као што је Crown Court или Виши суд чини се аутентичним читаоцу који говори енглески језик, односно читаоцу који говори српски језик. Функционална еквиваленција ствара везу, односно заједничку основу између преводиоца и читаоца. То је техника која омогућава читаоцу да се осећа сигурним док чита текст, јер термини с којима се сусреће припадају управо правном систему реципијента текста. Употреба појма познатог читаоцу допушта минимално разумевање, или бар илузију разумевања, што је за неке јуритрадуктологе „идеалан начин превођења" (в. Вестон 1991: 23). Другим речима, можемо рећи да је могуће, чак и пожељно, посегнути за овом техником у тексту намењеном „широј јавности” (књижевни преводи, преводи новинских чланака и сл.).

С друге стране, у тексту намењеном правним стручњацима, овом техником треба руковати врло опрезно јер скрива одређени број опасности. Уколико се не узимају у обзир опасности које може произвести функционална еквиваленција, у тексту који је превод може доћи до озбиљних значењских мимолилажења.

Један од несклада може се изазвати управо код назива правних актера, где ова техника може довести до аномалија, као што је, на пример евентуални еквивалент avocat général/procureur = јавни правобранилац. Иако може деловати веома примамљиво за преводиоца који је почетник и који жели да користи своје знање о другој цивилизацији, наведени пример функционалне еквиваленције је најблаже речено нескладан у француском контексту (о томе в. Стефановић 2016: 11).

Други озбиљан недостатак овога типа превођења је тај што оно некада може бити извор нејасноћа. У случају сумње, потребан је поновни превод (pemponpeвод/backtranslation) који омогућава верификацију подударности између оригиналног израза и његовог еквивалента. Ако се вратимо на први пример наведен у овом одељку, односно ако бисмо функционални еквивалент Виши суд навели без француског израза, поновни превод (ретропревод) би произвео или cour d'assises или tribunal pour enfants (cyд за малолетнике). Забуна која би у овом случају могла да настане је очигледна, јер ова два израза нису замењива.

Трећи значајан проблем који може изазвати функционална еквиваленција је разлика која се јавља између одређених референата што чини еквиваленцију неефикасном за стручњака. Дакле, еквиваленција juge d'instruction = examining magistrate односно juge d'instruction = истражни судија иако је добро утемељена у традицији превођења, она је само привидна еквиваленција у првом случају, односно она је нефункционална у другом случају, јер истражни судија више не постоји у српском правном систему. Examining magistrate је онај који организује прелиминарно саслушање како би проверио да ли постоје довољни докази за подизање оптужбе против осумњиченог, што је данас у Србији функција судије за претходни поступак. На овом месту занимљиво је указати на то да је управо скорашња промена у правном систему у Србији изазвала овакву ситуацију код српског еквивалента француском термину juge d'instruction јер је заправо некадашњи истражни судија имао 
функцију какву у француском правосуђу још увек има juge d'instruction. Из примера који смо овде навели, закључује се да је преводилац у обавези и да активно прати евентуалне промене правних система у државама са чијег језика се преводи и језик земље на чији се правни систем односи преведени документ.

Када је реч о функционалној еквиваленцији, значајно је запазити да је она заправо усмерена на језичко-правно-културолошки ограничену публику. То значи да израз Crown Court има смисла само за британског читаоца, односно Виши суд само за српског читаоца, као што cour d'assises има смисла само за француског. Заправо, ова техника се састоји у превођењу једне културне специфичности у другу културну специфичност, те подразумева двоструку призму, која уместо да појасни појам и његово значење, она га може учинити нејасним.

На идеолошком плану та техника може се чинити као етноцентрична. Када се преводи на језик земље која је политичко-економски доминантна, функционална еквиваленција може бити схваћена као форма културног империјализма пошто је један културни факт сагледан кроз перспективу доминантног језика. С друге стране, ако се преводи на језик лингвистички мање заједнице, ова техника постаје начин афирмисања њеног културног идентитета.

Формална еквиваленција је ,језичка” еквиваленција која има за циљ да код превођења правнога текста, односно, правне терминологије пружи превод који је готово дослован. Примери формалне еквиваленције су многобројни и могу се наћи углавном у називима институција и правних актера. Чести примери су: Conseil constitutionel = уставни савет; éducateur = едукатор. Код примера о којима је реч значајно је запазити неколико важних чињеница. Најпре, у првом случају (Conseil constitutionel) превод је веома успешан јер представља потпуни еквивалент. Међутим, други пример који смо навели éducateur = едукатор није добар, зато што српски правни систем не познаје ово занимање. Наиме у Француској éducateur као именица може бити додељена било коме ко се бави подучавањем, а такав случај је, колико видимо од скоро и у Србији. Међутим, у француском правном систему éducateur је конкретно занимање. То је особа која брине о малолетном деликвенту, односно надгледа и прати да ли малолетни преступник похађа школу, да ли ради, како се понаша и укратко помаже младој особи да се социјализује и врати у друштвено-правни систем земље. Такво занимање не познаје српски правни систем. Део послова који се тичу ресоцијализације у Србији може евентуално обављати социјални радник. Али и француски правни систем познаје занимање assistant social = couијални радник, иако се у Француској социјални радник врло ретко бави деликвентима и ресоцијализацијом. С обзиром на описану ситуацију код наведених термина, може се закључити да ни еквиваленција éducateur = соиијални радник није адекватна.

Неки пут случајности језика и историје проузрукују да формална еквиваленција представља и функционалну еквиваленцију са могућим анахронизмом: на пример код назива појединих институција, cour d'appel = апелациони cyd; cour de cassation = касациони суд; tribunal de commerce $=$ трговачки суд 
(од првог јануара 2010. предмете за које је он био до тада надлежан преузео је привредни суд, што је још конкретнији формални еквивалент, в. Стефановић 2018: 359). Једнакост формалне и функционалне еквиваленције можемо приметити и код појединих назива за правне актере: avocat $=$ aдвокат, notaire $=$ notar (односно данас јавни бележник - с тим што је та ситуација скорашња, јер пре последњих промена правног система у Србији послове које у Француској обавља нотар - notaire, у Србији је обављао углавном адвокат).

Ова техника еквиваленције, као и претходна, има своје предности и мане у односу на остале технике превођења. Међутим, овде је занимљиво приметити да су те предности и мане углавном супротне од предности и мана који се везују за функционалну еквиваленцију.

Важна предност формалне еквиваленције је то што је овај метод превођења транспарентан и недвосмислен, и дозвољава лако проналажење оригиналног термина. Дакле, појам попут notaire у француском правном систему, лако се враћа у одговарајући српски термин односно нотар, у случају ретропревода (лакше него на пример енглески или француски термини као што cy solicitor, conseil или avoué који изазивају потешкоће нарочито у преводу на српски језик). Овај критеријум је релевантан за стручњаке, који ће у неким ситуацијама морати да консултују и друге текстове, преведене или не, те ће им бити неопходно познавање терминологије језика пошиљаоца. Друга значајна предност ове технике је у томе што она на неки начин исказује веће поштовање према култури језика пошиљаоца, постављајући се на тај начин као антипод културног империјализма изазваног функционалном еквиваленцијом.

С друге стране, техника о којој је реч, ипак, има и одређене недостатке. Ти недостаци се првенствено виде у калковима или позајмљеницама као што су: сведок очевидаи, деликт за оно што француски систем познаје под терминима témoin assisté или délit (за које су ипак прикладније српске формулације „окривљени у ширем смислу” и „лакше кривично дело”; в. даље у овом тексту као и Стефановић 2018: 361; 2016: 9), а који могу створити негативну слику о преводиоцу, јер се може чинити да је превише везан за оригинални текст а такође, када је реч о позајмљеницама, као што смо већ видели у примеру éducateur = eдукатор, ова техника може довести до потпуно погрешног превода, јер превод може одступити од реалности, односно може довести до забуне у језику примаоцу.

Формални еквиваленти могу створити утисак незграпности у тексту или пак изазвати потешкоће у читању. То се уочава код еквивалената инструкuија = instruction који заправо нису поуздани еквиваленти. Наиме, француски израз instruction одговара српском изразу истрага, али има а приори значење речи наредба, што се у француском језику али и у француском правном систему може још означити и изразом ordre (= наредба). Код наведеног примера instruction = инструкција значењска еквиваленција не постоји, те формална еквиваленција не одговара законско правној стварности. Поред тога, управо из последњег примера можемо видети да се дословним преводом преводилац ставља у ситуацију у којој би могао уместо одговарајућег 
еквивалента употребити заправо „лажног пријатеља“, који су (делимични или потпуни) чести у правном преводу. Грешке овога типа могу се пронаћи и у стручним књигама, што илуструје пар: droit commun = onште право. То вероватно произлази из чињенице да српски преводиоци али и правни двојезични или тројезични речници не инсистирају довољно на двема врло важним карактеристикама француске правне терминологије: француски правни појмови могу бити „ексклузивни” тј. припадају само правном језику или пак „двоструки” тј. означавају фундаменталне појмове у праву, али такође припадају свакодневном језику, што, дакако, представља замку за преводиоца и тумача (о томе опширније в. Стефановић 2018: 357).

Формална еквиваленција открива баук дословног превода, који је, како на то указује Сузана Шарчевић (1997: 23-41), дуго вршио тиранију над правним преводиоцима. Јуритрадуктолози данас ипак не стављају акценат на идентитет формулација, већ на идентитет правних ефеката у две верзије истог текста (Шарчевић 1997: 16-19). Међутим, ова техника има предност и у томе што је детронизовала оригинални текст, истичући комуникативну функцију преведеног текста.

Преводилачка техника транскрипиија представља особену технику превода код које се репродукује оригинални термин са евентуалним додавањем глосе уз њега приликом првог превођења. Пример таквог превођења био би „cour d'assises - суд надлежан за тешка кривична дела, односно злочине” или „témoin assisté - лице за које се сумња да је учествовало у извршењу кривичног дела, али које још увек није стављено под истрагу". Ако је термин, који је репродукција оригинала, довољно транспарентан или је његово значење недвосмислено јасно на основу контекста, глоса није неопходна. Такав би био пример „О злочинима суди cour d'assises”.

Ова техника је у неким случајевима веома добра и корисна јер она не носи ризик да употребљени термин у преведеном тексту буде двосмислен или чак нејасан. Техника транскрипције нарочито је корисна у документима који се обраћају специјалистима за које су прецизност и јасноћа далеко важнији од елеганције и концизности. У крајњем случају, детаљна глоса може бити веома корисна у случајевима када је потребно да се читаоцу детаљно објасне значајне разлике између два система. У том контексту управо ова техника би била занимљива код француског правног термина „constitution de partie civile = страна која на суду наступа у име жртве, а у позищији онога који тужи осумњиченог”. Управо зато српски правни двојезични или тројезични речници привилегују ту технику (в. Јанковић/Ђуровић/Јанковић 1969, Стругар 1998, Кнежевић/Јовановић 2001, Јовановић/Тодоровић 2007, Варничић Донжон 2011, Радојковић Илић 2016; о томе опширније в. Стефановић 2018).

Ипак, неки стручњаци технику транскрипције сматрају за признање неуспеха (Вестон 1991 : 26). Она заиста може обесхрабрити повременог читаоца због њене тежине, а такође може представљати проблем и „мотивисаном” читаоцу који нема довољно знања о изворном језику те му је веома тешко да памти појмове који се понављају у документу. С обзиром на то да ова 
техника превођења захтева личне интервенције преводиоца, она постаје противна принципу дискретног преводиоца који се држи традиционалног принципа неличности у правном дискурсу. Међутим без обзира на то што се овом техником уводи лични став, запажање или коментар преводиоца, код неких термина она нам се може учинити апсолутно неопходном, какав је термин за професију познату француском, али не српском систему, односно за већ поменути израз е́ducateur.

Четврта техника превођења правних текстова била би дескриптивна транскрипција. Ова техника објашњава културне специфичности употребљавајући генеричне термине. То значи да она заправо нуди превод који је сажет али који функционише аутономно. На пример концепти у француском правном систему crimes, délits и infractions могу бити преведени као концепти српског правног система тежа кривична дела, лакша кривична дела и прекршаји (в. Стефановић 2016: 9).

Међутим, код ове технике превођења основни проблем представља то што је често веома тешко наћи адекватну сажету формулацију која неће изазвати двосмисленост. То је нарочито видљиво код примера као што је израз тежа кривична дела који при ретропреводу може да се разуме као еквивалент и за délits и за crimes. Како би се избегле овакве забуне и погрешке, пожељно би било, за сваки случај, ставити у заградама термине из оригиналног текста, односно називе језика пошиљаоца.

С друге стране, код језичко-правних ситуација у којима се овом техником могу наћи адекватни сажети и јасни преводи, дескриптивна транскрипција олакшава читање и разумевање правнога текста. Она тако подједнако може одговарати и оним читаоцима који нису стручњаци, али и стручњацима из правне струке. У суштини она представља компромис између типа превода који привилегује културу језика пошиљаоца, и функционалне еквиваленције, која акценат ставља на културу језика примаоца.

Када се пажљиво анализирају ове четири технике, уочава се да су транскрипција и формална еквиваленција преводилачког континуума која предност даје култури језика пошиљоца, с једне стране, док је насупрот њих техника функционалне еквиваленције, код које се предност даје култури и језику на који се текст преводи. Између ових крајњих полова стоји техника дескриптивне транскрипције. Оваква шема одражава две тенденције упоредног права које могу бити окренуте или према систему пошиљаоцу или према систему примаоцу, на шта је указао и Џемисон 1996.

Коју ће технику од ове четри технике превођења одабрати преводилац, зависи од више разлога: естетских, идеолошких, и пре свега од комуникативних. Преводилац такође мора узети у обзир и онога коме се обраћа, односно сврху за коју преводи. Нарочито се пажљиво мора приступити правним документима који се преводе за потребе неког судског, односно, правног процеса, јер управо код ових превода последице неадекватног превода могу бити далекосежне. Такође, са техникама превода треба пажљиво руковати код текстова намењених стручњацима у сврхе упоредног изучавања два правна система, као и уопштено у текстовима који су намењени стручњацима. С друге 
стране, правни текстови намењени широј публици, могу се лакше ослонити на технике које примат дају језику примаоцу, јер је пожељно да ти текстови буду у духу културе и језика на који се преводи, како би били пријемчивији за читање.

\section{ЛИТЕРАТУРА}

Варничић Донжон 2011: Н. Варничић Донжон, Франиуски језик у праву, Београд: Правни факултет Универзитета у Београду.

Вестон 1991: M. Weston, An English Reader's Guide to the French Legal System, New York/Oxford: Berg.

Вине/Дарбелне ${ }^{2}$ 1977: J.-P. Vinay, J. Darbelnet, Stylistique comparée du français et de l'anglais, Paris: Didier.

Давид/Жофре/Спинози 101992: R. David, C. Jauffret-Spinosi, Les grands systèmes de droit contemporains, Paris: Dalloz.

Јанковић/Ђуровић/Јанковић 1969: М. Јанковић, Р. Ђуровић, Р. Јанковић, Економско-правни речник српскохрватско-франиуско-немачки, Београд: Међународна политика.

Јовановић/Тодоровић 2007: Ј. Јовановић, С. Тодоровић, Речник правних термина српско-енглеско-франщуски, Београд: Савремена администрација.

Кнежевић/Јовановић 2001: М. Кнежевић, К. Јовановић, Економско-финансијски франиуско-српски речник, Београд: Просвета.

Максимовић 2006: Е. Максимовић, Јурислингвистика као спона између правних и језичких наука, у: М. Мићовић (ред.), Зборник Право и језик, Крагујевац: Правни факултет Универзитета у Крагујевцу, Институт за правне и друштвене науке, 163-173.

Радојковић Илић 2016: К. Радојковић Илић, Le français juridique - Франиуски језик у праву, Београд: Правни факултет Универзитета у Београду.

Редли 2019: Ј. Редли, Несистематски спојеви речи у правним текстовима, Научни састанак слависта у Вукове дане, 48/1, 227-228.

Рива 1981: N. Riva, Droit public et traduction, Montréal: Meta, 26/3, Les Presses de l'Université de Montréal, 223-236.

Стефановић 2016: А. Стефановић, Нека запажања из области превода/тумачења судско-кривичне терминологије с француског језика на српски језик, Научни скуп филозофског факултета, 10/2, Пале, Сарајево, 10-18.

Стефановић 2018: А. Стефановић, Анализа француско-српских правних речника, Научни састанак слависта у Вукове дане, 47/1, 355-363.

Стругар 1998: Н. Стругар, Српско-франиуски речник Политика-Право-Економија, Београд: Удружење научних и стручних преводилаца Србије.

Tома 2018: P-L. Thomas, L'intraduisible du BCMS, in: O. Artzushkina, Ch. Zaremba (dir.), Propos sur l'intraduisible, nouvelle édition [en ligne], Aixen-Provence: Presses universitaires de Provence. 
Чалмерс 1994: R. Chalmers, Murder on the Riviera, London: The Observer Magazine, 12-16.

Џемисон 1996: N. Jamieson, Source and Target-Oriented Comparative Law, American Journal of Comparative Law, 44/1, Oxford: Oxford University Press, 121-129.

Шарчевић 1997: S. Šarčević, New Approach to Legal Translation, The HagueLondon-Boston: Kluwer Law International.

Шарчевић 2012: S. Šarčević, Challenges to the Legal Translator, in: U. Tiersma, P.-M. and L.-M. Solan, The Oxford Handbook of Language and Law, Oxford: Oxford University Press, 187-200.

Alexandar D. Stefanovic

\section{STRATÉGIE D'ÉQUIVALENCE DANS LA TRADUCTION JURIDIQUE OU COMMENT TRADUIRE L'INTRADUISIBLE ENTRE FRANÇAIS ET SERBE}

\section{Résumé}

Dans cet article nous avons tenté de mettre en exergue les différentes stratégies employées lorsqu'il est nécessaire d'exprimer en serbe ou en français une notion spécifique à un autre systéme juridique. Quatre techniques sont analysées : l'équivalence fonctionnelle, l'équivalence formelle, la transcription et la traduction descriptive. Chacune de ses techniques a des conséquences tant sur le plan communicatif qu'idéologique, conséquences que les traducteurs, auteurs et lexicographes serbes doivent prendre en considération.

Mots clés: serbe, français, traduction juridique, équivalences, stratégies. 